\title{
Final das Olimpíadas de Química Júnior
}

A final das Olimpíadas de Química Júnior decorreu no dia 5 de maio no Instituto Superior Técnico da Universidade Técnica de Lisboa (IST/UTL).

Como previsto, compareceram as 20 equipas apuradas para esta final, vindas de 19 escolas. Pelas $10 \mathrm{~h}$ teve lugar a sessão de boas-vindas, num dos anfiteatros da Torre Sul. Seguiu-se a prova que terminou pouco depois do meio-dia. Os participantes foram agrupados em 4 grupos (alcalinos, gases raros, halogéneos e lantanídeos), tendo cada um deles feito um percurso por 6 locais de prova, entre anfiteatros e laboratórios. Houve questionários sobre Química e Cidadania, Química num dia da vida do João, Quizz de Química e Caça ao Químico e outras questões, com componente experimental, Rally Químico e Química em Acção. Enquanto os participantes cumpriam a prova, os professores acompanhantes foram convidados a visitar a exposição da Profa Clementina Teixeira, "Os artesãos da Química".

Depois de um final de manhã bastante movimentado, alunos e professores almoçaram na cantina dos Serviços de Acção Social da UTL no Técnico. Houve ainda tempo para relaxar e passear pelo campus do IST-Alameda, até que pelas $14 \mathrm{~h}$ se iniciou o sempre agitado e muito interativo "Show de azoto", pela Profa Clementina Teixeira. Pouco depois das quatro horas da tarde, teve então lugar a sessão de encerramento, que contou com a presença do Prof. Mário Nuno Santos, Presidente da SPQ, e a tão ansiada divulgação dos resultados.

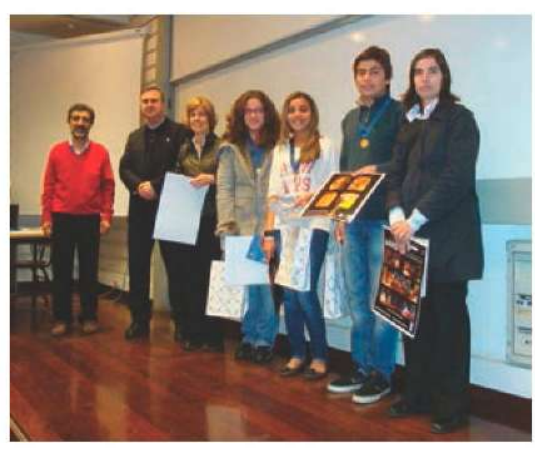

1. "Lugar - "QUÍMICA NA ROQUE" da Escola Básica 2,3 Roque Gameiro (Amadora)

Raquel Gama

Jéssica Soares

Pedro Reis

2. ㄴugar - "OS BASTOS" da Escola Básica e Secundária de Cabeceiras de Basto

Joaquim dos Santos

Daniela Basto

Sara Dourado

3. 'Lugar - "BOSCO III" da Escola Salesiana do Estoril

Bruno Oliveira

Francisco Traquete

Martinho Fé Santos

É de referir que as classificações obtidas pela generalidade das equipas foram muito altas, mostrando uma boa preparação dos alunos. Terminada a sessão, foi oferecido a todos os parti-

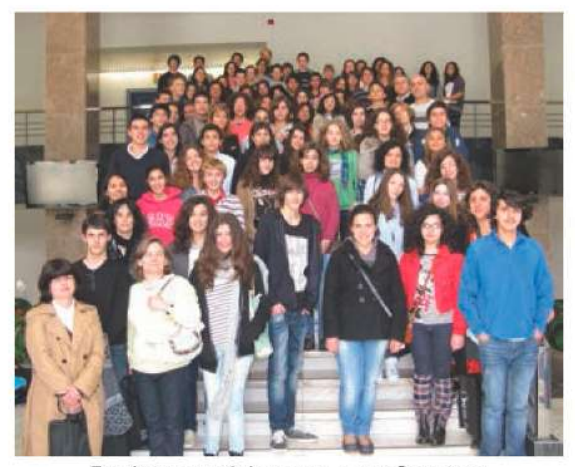

Equipas participantes e professores acompanhantes

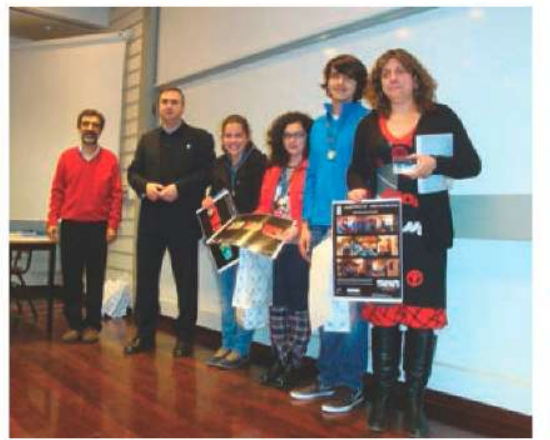

cipantes um lanche para recuperarem forças para a viagem de regresso.

Queremos agradecer aos estudantes do Núcleo de Engenharia Química do IST e estudantes de pós-graduação do IST pela preciosa ajuda no acompanhamento das provas; a professores do Departamento de Engenharia Química, alguns no acompanhamento da prova e outros na correção das respostas; e à Reitoria da UTL, na pessoa do Sr. Reitor, Prof. António Serra, pela oferta dos almoços e lanches. Queremos também agradecer a todos os alunos que participaram nestas provas e aos professores acompanhantes, muitos deles já "repetentes" nestas andanças e a quem, no fim de contas, se deve a mobilização de muitas centenas de alunos para as Olimpiadas organizadas pela SPQ. Esperamos que, apesar dos tempos difíceis que vivemos, possamos manter este elevado nível de mobilização de alunos e professores em torno da Química.

Jorge Morgado (jmfmorgado@ist.utl.pt)

IST/UTL

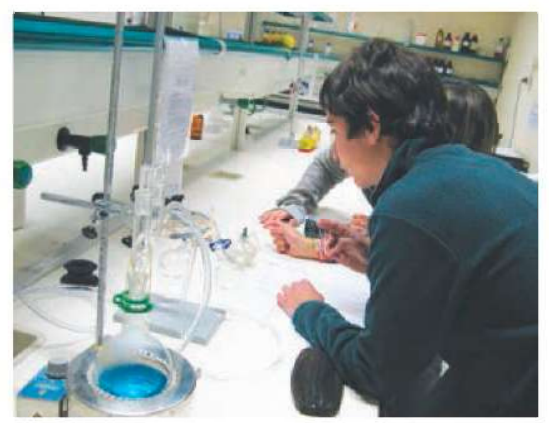

Realização de provas pelos alunos

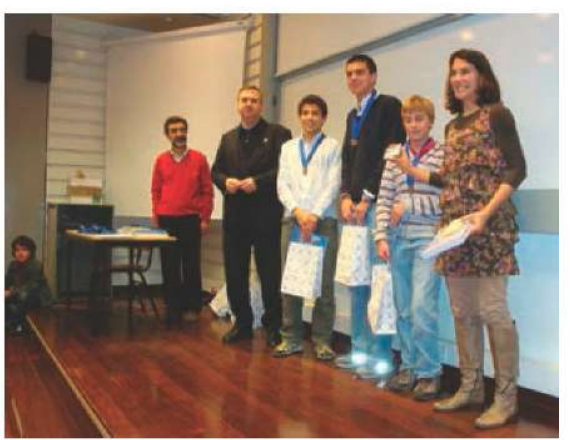

Da esquerda para a direita: equipas vencedoras classificadas em $1 .^{\circ}, 2 .^{\circ}$ e $3 .^{\circ}$ lugares, respetivamente 